\title{
Environmental and Energy Taxation and State Aid Control: Does the Current Framework Make Sense or Should It Be Adjusted?
}

Energy taxation is a key tool to fight climate change and promote green energies. However, tax reliefs for so called environmental purposes are frequent. Member States are in principle sovereign to decide energy taxation and also environmental tax reliefs but they have to respect the EU and international rules, in particular the Energy Taxation Directive (ETD), the Single Market Rules, the State Aid control system and the WTO rules.

With regard to the State aid regime, the main current legal framework is contained in the General Block Exemption Regulation (GBER) and the Commission's Guidelines on State aid for environmental protection and energy 2014-2020 (EEAG). But does this framework make sense or should it be adjusted? How is it compared with the US system? Are the WTO rules adequate?

Many of the contributions to this issue precisely explore the intersection between energy taxation, environmental protection, and competition and trade law. They are the result of a Jean Monnet research project ("Energy Taxation and State Aid Control: Looking for a Better Coordination and Efficiency"), coordinated by Marta Villar Ezcurra and fostered by the Centre for Competition Policy (Institute for European Studies at CEU San Pablo University) directed by Jerónimo Maillo (more info at http://www.idee.ceu.es). The project aimed at clarifying the role of tax benefits in the energy sector and specifically the relationship between State aid control and the European taxation on energy, by identifying the most suitable mechanisms to reconcile competitiveness, environmental protection and the need for tax resources, from both the point of view of the effectiveness of the measures and the coherence of the legal system.

The conclusions of the project pointed out that (1) There is a need for a refined use of legal concepts: in particular, the reference to 'environmental tax' in State aid law may be problematic and the uncertainty caused by this term can distort the conceptual and legal framework of State aid rules; (2) There is a need for further and stricter rules to prove the necessity and proportionality of the restriction (e.g. incentive effect and closer link between environmental protection and competitiveness). The rules of both the GBER and the EEAG leave a too wide leeway to Member States; (3) Consequently, a change of both the GBER and the EEAG is desirable.

Some of the contributions in this issue (e.g. Villar, Maillo) explain these conclusions, analyse the alternatives and suggest reform proposals. We have also tried to put the analysis into a broader comparative law and international law context (e.g. Milne and Pirlot).

We are grateful to the editors of EStAL, especially to José Luis Buendía and Caroline Buts, for giving us the opportunity to co-edit this issue and spread out the outcome of the research project.

Marta Villar Ezcurra and Jerónimo Maillo*

* CEU San Pablo University, Madrid. 